\title{
Application of GFPuv Labeled Cronobacter sakazakii for Evaluation of Its Survival during Cornstarch Processing
}

\author{
Siti Nurjanah ${ }^{1,2^{*}}$, Sarah Tiara Sulistyanti1, Ratih Dewanti-Hariyadi ${ }^{1,2}$ \\ ${ }^{1}$ Department of Food Science and Technology, Faculty of Agricultural Engineering and Technology, Bogor \\ Agricultural University, Bogor, Indonesia \\ ${ }^{2}$ SEAFAST Center, Bogor Agricultural University, Bogor, Indonesia \\ Email: ${ }^{*}$ siti.nrih@gmail.com
}

Received 10 June 2015; accepted 20 August 2015; published 25 August 2015

\begin{abstract}
Cronobacter sakazakii is an emerging pathogen that can cause diseases for several infant groups. These bacteria were contaminated in foods, clinical utensils, and environments. In Indonesia, $C$. sakazakii has been isolated from powdered infant formulas, weaning foods, and other dried foods such as cornstarch. The objective of this research is to trace survival of $C$. sakazakii during cornstarch production step using its mutant. Mutant was constructed by inserting Green Fluorescent Protein plasmid inside to the bacterial cell that appeared green fluorescent colonies under UV observation. The presence of $\boldsymbol{C}$. sakazakii during processing was conducted by artificial contamination. This research consists of three steps, i.e. determination of the suitable enumeration method of $C$. sakazakii's mutant, cornstarch production from yellow corn, and survival analysis of C. sakazakii during endosperm soaking and cornstarch drying. The suitable enumeration method was surface plating method on TSA-ampicillin medium combining with UV light application because of ineffectiveness of ampicillin inhibition for growth of yeasts and molds. The cornstarch produced in laboratory has the same properties with commercial cornstarch in parameters of moisture content, density, and starch granule structure. The yield of cornstarch final product was $48.90 \%$ (dry whole kernel-based). $C$. sakazakii cannot survive in 48 hours soaking process at $52^{\circ} \mathrm{C}$ and 24 hours drying process at $50^{\circ} \mathrm{C}$ that is applied during cornstarch production.
\end{abstract}

\section{Keywords}

Cronobacter sakazakii, Cornstach, Green Fluorescent Protein, Processing, Survival

\section{Introduction}

Cronobacter sakazakii is a gram-negative bacterium which is included into genus of Cronobacter spp. (previously known as Enterobacter sakazakii). C. sakazakii is an opportunistic pathogen that causes meningitis and necrotizing enterocolitis for adverse condition of infant groups. These cases are associated with infant formulae

"Corresponding author.

How to cite this paper: Nurjanah, S., Sulistyanti, S.T. and Dewanti-Hariyadi, R. (2015) Application of GFPuv Labeled Cronobacter sakazakii for Evaluation of Its Survival during Cornstarch Processing. World Journal of Engineering and Technology, 3, 1-6. http://dx.doi.org/10.4236/wjet.2015.33B001 
consumption that contaminated by this pathogen [1]. In Indonesia, Cronobacter spp. has been isolated [2]-[5]. All of the isolates were obtained from dried food products, i.e. powdered infant formula, weaning food, rice flour, tapioca, cornstarch, sugar, cocoa powder and dried spices, suggesting that they were able to survive drying. The data reported by FAO-WHO [6] showed that the ingredient added through dry mixing process was one of the sources of Cronobacter spp. contaminant in powder infant formulae. Current researches supported this issue, Dewanti-Hariyadi et al. [7] have isolated Cronobacter spp. from cornstarch and Fiegen [8] have isolated the pathogen form cornstarch and other ingredients (lecithin, potato starch, rice starch and wheat starch).

Cornstarch was chosen as a food model in this study due to its widespread use as ingredient for infant food products. It is important to understand survival of Cronobacter spp. during cornstarch production due to its presence in final products. Besides, it is important to understand the step that can reduce this microorganism and how much the reduction of this microorganism is during cornstarch production. In the cornstarch processing, corn soaking and drying step are the expected step to reduce the number of microbial contamination. Soaking the corn grits is carried out at $52^{\circ} \mathrm{C}$ for 48 hours and drying is carried out at a $50^{\circ} \mathrm{C}$ for 24 hours. Therefore, in this study, the aim is to check effectiveness of both processes in reducing $C$. sakazakii that occur in the corn grits by artificial contamination. The objective of this research was to evaluate the survival of C. sakazakii during cornstarch processing, especially in soaking and drying step used moderate temperature application. Contamination was conducted by artificial contamination by challenging the mutant isolates to the maize grits amongst the indigenous microflora. The suitable method for enumerating the mutant in the presence of other microorganisms (lactic, yeasts and molds) was part of this study. For specific enumeration, C. sakazakii is labeled by a Green Fluorescent Protein (GFPuv) into bacterial cells as a marker then called a C. sakazakii mutant. GFP is a protein from jellyfish (Aequorea Victoria) which can fluoresce and its gene has been inserted into a plasmid (pGFP) as a vector. The pGFPuv is a GFP variant plasmid having fluorescence signal 45-fold greater than a standard pGFP. The mutant can grow in ampicillin containing medium and is seen as a green fluorescent colony. The GFPuv labeled have been constructed for C. sakazakii isolates FWHc3 and YRt2a [9].

\section{Methodology}

\subsection{Materials}

Microorganisms used in this study were GFPuv labeled of C. sakazakii FWHc3 and YRt2a constructed from previous research [9], yeasts (Kodamaea ohmeri, Candida krusei, Candida zeylanoides), and molds (Aspergillus flavus, Aspergillus niger, Fusarium oxysporum) and lactic bacteria (Pediococcus sp., Lactobacillus plantarum, Lactobacillus lactis, Lactobacillus brevis) isolated from previous research [10]. All of isolates are collection culture of Microbiology Laboratory of SEAFAST Center Bogor Agricultural University. Mutants (GFPuv labeled of $C$. sakazakii FWHc3 and YRt2a) were confirmed by growing on $100 \mu \mathrm{g} / \mathrm{mL}$ ampicillin containingTriptic Soy agar medium (TSAA), incubated overnight at $37^{\circ} \mathrm{C}$ and observed under UV light (Desaga Heidelberg Min UVIS). Materials used in this study were Pioneer variety corn originated from West Java, microbial medium TSA (Tryptone Soy Agar), BHI (Brain Heart Infusion), BPW (Buffered Peptone Water), PDA (Potato Dextrose Agar), MRSB (De Man Rogosa Sharp Broth), NB (Nutrient Broth), ampicillin, natrium hipoklorit (NaOCl) $2 \%$.

\subsection{Comparison of Surface and Pour Plating Technique for Mutant Enumeration}

Overnight cultures of each mutant isolates from the stock were diluted and plate onto TSAA medium. Plating methods were conducted by two techniques, i.e. spread onto surface agar medium and pour plate method. The plates were incubated for $24 \mathrm{~h}$ (ca. $10^{8}-10^{9} \mathrm{CFU} / \mathrm{mL}$ ), and the numbers of total and green fluorescent colonies were determined. Green colonies presence was calculated as the ratio between the plate counts of green fluorescent colonies and the total counts obtained from the ampicillin medium plates and expressed in percentage. The effective plating method was chosen from two plating techniques that provide higher percentage of green colonies presence.

\subsection{Evaluation of Ampicillin Inhibition to Growth of Yeasts, Molds and Lactic}

The cocktail culture of molds (A. flavus, A. niger, F. oxysporum) was prepared by mixing at the equal proportion of each spore solution (1:1:1) that were obtained from watery agar slant of each isolates. The cocktail culture of yeasts (K. ohmeri, C. krusei, C. zeylanoides) was prepared by inoculating an overnight culture of each yeast iso- 
lates in broth medium (NB). The cocktail culture of lactic bacteria (Pediococcus sp., L. plantarum L. lactis) was prepared by the similar technique with yeast. Evaluation of ampicillin inhibition for lactic, yeasts and molds was conducted by plating each cocktail culture separately on TSAA medium using various concentrations of ampicillin $(0,25,50,75$, and $100 \mu \mathrm{g} / \mathrm{mL})$. Each mixed cultures was diluted four folds of dilution using dilute solution BPW, and plated with TSAA medium. The plates were incubated at $30^{\circ} \mathrm{C}$ (yeast and mold) and at $37^{\circ} \mathrm{C}$ (lactic bacteria) for 48 hours. The amount colonies of each plate were determined by semi qualitative expression based on the standard plate. It was expressed by negative $(-)$ if there is no colony grown. It was expressed as $1+, 2+$, $3+4+$ or $5+$, corresponding to approximately $\leq 10,25,50,75$ or $\geq 90 \%$ of colonies grown in plate respectively.

\subsection{Cornstarch Production and Properties Analysis}

Dried corn kernels were grinded by the disc mill to produce grits. Any impurities were separated from the corn grits. Corn grits were washed and cleared from the germ and pericarp (bran) [11]. The endosperms were soaked in $0.25 \%$ sodium bisulfite solution in ratio of $1: 5$ ( 1 part corn: 5 parts the solution) for 48 hours at a temperature of $52^{\circ} \mathrm{C}$. After soaking, the endosperms were ground using a grinder with additional water then filtered using a screen. The suspension resulted from the filtration was precipitated for minimum 12 hours to precipitate the starch and separate the protein. The precipitated starch was dried by oven at $50^{\circ} \mathrm{C}$ for 24 hours. The dried starch was powdered using a blender and sieved using a 100 mesh sieve to obtain cornstarch powder. The yield of cornstarch processing was calculated based on the dry whole corn kernel. Cornstarch produced was analyzed for moisture content by oven method, whiteness by whiteness meter, density and structure of starch granule by polarized microscope. In order to compare the properties, a commercial cornstarch was also analyzed.

\subsection{Artificial Contamination and Survival Analysis}

Artificial contamination was conducted by challenging the C. sakazakii mutant FWHc3 and YRt2a separately in two step of processing during cornstarch manufacturing. The growth pattern of two mutants was compared. The first artificial contamination was conducted in endosperm grits before soaking step. One milliliter of each $C$. sakazakii mutant (ca. $10^{8} \mathrm{CFU} / \mathrm{ml}$ ) was inoculated into $20 \mathrm{~g}$ of endosperm grits placed in sterile bottle, and allowed to contact for 15 minutes. After 15 minutes, $100 \mathrm{ml}$ of soaking solution (contained $0.2 \mathrm{~g}$ of sodium bisulfite) was added into the jar and stirred for homogenization. Soaking step was conducted at a $52^{\circ} \mathrm{C}$ for 48 hours. The second artificial contamination was conducted in starch before drying step. One milliliter of each mutant was inoculated into $35 \mathrm{~g}$ starch suspension placed in the bottles, and stirred. The suspension was transferred to a baking plate which sized $18 \times 18 \mathrm{~cm}$. Then covered by the filter paper that is perforated at the four corners with a size of $2 \times 2 \mathrm{~cm}$. Drying was carried out using oven at $50^{\circ} \mathrm{C}$ for 24 hours.

Enumeration the number of $C$. sakazakii was done from $10 \mathrm{~g}$ sample from each treatment, prepared serial dilutions appropriate and plated in the TSAA medium using surface plating method. The green fluorescence colonies were counted under UV light followed 24 hours incubation. Bacterial colonies are calculated by Standard Plate Count [12] and converted in log units. Reduction curve C. sakazakii is created by plotting the number of colonies (logarithmic) in sample on the $\mathrm{Y}$ axis and the time interval (hours) on the $\mathrm{X}$ axis.

\section{Result and Discussion}

\subsection{Comparison of Surface and Pour Plating Technique for Mutant Enumeration}

Surface and pour plating techniques were techniques for enumerating the number of microorganisms by growing the cell on agar medium to build visually sized colonies. Pour plating technique is commonly used for total plate count. Surface plating technique is used for enumeration aerobic obligate microorganisms or for specific purposes. In this study, these two techniques were compared and selected as a suitable method for enumerating the C. sakazakii mutants that are capable of remaining of fluorescence characteristics in medium. The suitable method was confirmed as the technique that provided higher percentage of green fluorescent colonies.

Pour plating technique resulted the percentage of green fluorescent colonies of $C$. sakazakii mutants FWHc3 and YRt2a were $91.48 \%$ and $89.75 \%$ respectively (based on the total colonies) (Table 1). It indicated that nearby one log cycle differences of number colonies did not appear the fluorescence under UV light observation, especially which colonies grown in the bottom of plate. It can lead a falls negative identification if the mutant is applied for the qualitative identification. If the mutant is applied for the quantitative application, it can allow the 
Table 1. Comparison of surface and palting technique analysis.

\begin{tabular}{ccc}
\hline \multirow{2}{*}{$\begin{array}{c}\text { Plating } \\
\text { technique }\end{array}$} & Fluorescent colonies percentage of isolates (\%) & \\
\cline { 2 - 3 } & FWHc3 mutant & YRt2a mutant \\
\hline Pour Plate & 91.48 & 89.75 \\
Surface Plate & 100 & 99.98 \\
\hline
\end{tabular}

lower quantity than the actual number of these bacteria. Surface plating technique showed higher fluorescent colonies percentage is $99.98 \%$ for YRt2a mutant and $100 \%$ for FWHc3 mutant. The surface technique allowed the directly exposure of UV light to the chromophore ring protein in GFPuv resulted the fluorescence intensity of the colony. Therefore, surface plating method is suitable plating method for enumeration of GFPuv bacterial mutant.

\subsection{Ampicillin Inhibition to Growth of Yeasts, Molds and Lactic}

Several types of microorganisms can be found in corn kernel or grits during cornstarch processing as indigenous micro flora or as a contaminant. Several yeasts (K. ohmeri, C. krusei, C. zeylanoides), molds (A. flavus, A. niger, F. oxysporum), and lactic bacteria (Pediococcus, L. plantarum, L. lactis, L.brevis) have been found in the corn kernel [10]. For tracing the $C$. sakazakii survival or reduction during cornstarch processing, the presence of these microorganisms can offer the disorder counting result. The ampicillin supplemented into the medium used for mutant enumeration does not avoid these microorganisms to grow. Cocktail culture of yeasts (K. ohmeri, C. krusei, C. zeylanoides), molds (A. flavus, A. niger, F. oxysporum), and lactic bacteria (Pediococcus, L. plantarum, L. lactis, L.brevis) showed the different ampicillin resistance patterns (Figure 1). Yeasts and molds did not show the decrease of their number against the ampicillin concentration up to $100 \mathrm{ug} / \mathrm{ml}$. It was concluded that ampicillin was ineffective to inhibit the growth of fungi and yeasts, because the mechanism of this antibiotic was to inhibit peptidoglycan synthesis in microbial cell wall during cell growth [13]. Gram Positive bacteria have a rich peptidoglycan structure in their cell wall while yeasts and mold do not have.

Unlike yeasts and molds, lactic bacteria showed slightly declined by the increasing concentration of ampicillin (Figure 1). Lactic bacteria are grouped to Gram Positive bacteria. However, there are some strain sensitive and some strain resistance to ampicillin. Pediococcus is resistant to ampicillin, whereas Lactobacillus rhamnosus is sensitive to ampicillin [14]. Lactobacillus, S. thermophilus and Leuconostoc are not the ampicillin resistance [15]. Ampicillin sensitive of lactic is caused by mechanism of ampicillin to inhibit the enzyme that functions in the formation of peptidoglycan structures in the cell walls of bacteria [16]. While the ampicillin resistant of lactic can be caused by enzymatic degradation of antibiotic compounds, changes in bacterial protein target structure or changes in the permeability properties of the membrane to the antibiotics [17]. The ampicillin resistance capability of other microorganisms is caused that ampicillin supplemented medium is not a specific method for mutant enumeration. Therefore, it is required combining by other techniques to complete as function as a specific method. The UV light application is absolutely required for completing the detection method. All of yeast, molds and lactic bacteria grown in ampicillin were not fluoresce under UV light.

\subsection{Cornstarch Properties}

Production of cornstarch from yellow corn yielded amount 48.90\% (based on dry corn kernels) of cornstarch. The cornstarch produced in laboratory has the similar properties with commercial cornstach in parameters of moisture content, density, and starch granule structure (Table 2). Whiteness properties were different due to the difference of used corn varieties. Water content of both type of cornstarch was similar and the values complied with the standard. The starch granules have the similar shape and size. Similarity of two cornstarch properties is associated with the similarity of manufacturing process. According to that, corn soaking step at temperature of $52^{\circ} \mathrm{C}$ for 48 hours and drying step at temperature of $50^{\circ} \mathrm{C}$ for 24 hours can be applied in this study for evaluation the survival or the reduction the $C$. sakazakii mutants.

\subsection{Survival and Reduction of C. sakazakii}

Survival or reduction of $C$. sakazakii during soaking and drying step were evaluated using FHWc3 and YRt2a 


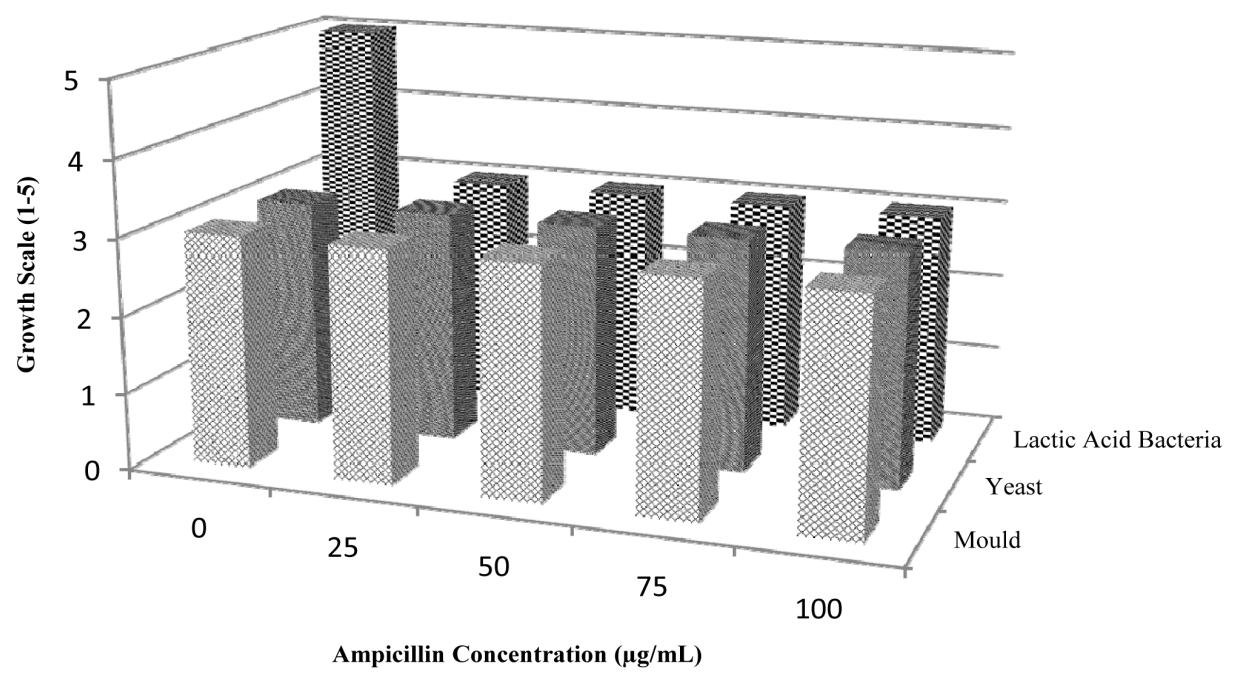

Figure 1. Effect of ampicillin to growth of yeasts, molds and lactic.

Table 2. Comparison of properties of laboratory and commercial cornstarch.

\begin{tabular}{ccccc}
\hline \multirow{2}{*}{$\begin{array}{c}\text { Type of } \\
\text { cornstarch }\end{array}$} & $\begin{array}{c}\text { Moisture content } \\
\text { (\% dried based })\end{array}$ & $\begin{array}{c}\text { Density } \\
(\mathrm{g} / \mathrm{mL})\end{array}$ & $\begin{array}{c}\text { Whiteness } \\
(\%)\end{array}$ & $\begin{array}{c}\text { Starch } \\
\text { granules size }\end{array}$ \\
\cline { 2 - 5 } & 9.90 & 0.4410 & 85.54 & $2.5-15 \mu \mathrm{m}$ \\
\hline $\begin{array}{c}\text { Produced } \\
\text { from } \\
\text { laboratory }\end{array}$ & 9.02 & 0.4340 & 128.19 & $2.5-15 \mu \mathrm{m}$ \\
\hline
\end{tabular}

mutant separately. Survival was determined by enumerating the mutants that remain viable after the soaking and drying step respectively. The initial number of FWHc3 and YRt2a mutants before the soaking treatment were 7.05 and $5.51 \log \mathrm{CFU} / \mathrm{g}$ respectively. The result showed that after soaking step there didn't detect any mutant remain viable (LOD $=1 \log \mathrm{CFU} / \mathrm{g}$ ). It is concluded that soaking step for 48 hours at $52^{\circ} \mathrm{C}$ is effective to reduce Cronobacter. The growth temperature range of Cronobacter spp. is $6{ }^{\circ} \mathrm{C}-47^{\circ} \mathrm{C}$ [18] and the $\mathrm{D}_{52}$ value of Cronobacter spp. is 54.8 minutes [19]. The $\mathrm{D}$ value indicates the time required to reduce the amount of spore or vegetative cell by $90 \%$ or one logarithm cycle [20].

The initial number of FWHc3 and YRt2a mutants before the drying treatment were 4.37 and $4.81 \mathrm{log}$ CFU/g respectively. The result showed that after drying step for 6 hours, the number of FWHc3 and YRt2a mutants decreased to 2.19 and $1.45 \log$ CFU/g respectively. The FWHc3 and YRt2a mutants survived in the short term of drying. When the drying process was continuing up to 24 hours, there was no detected any mutant remain viable. It is concluded that drying step for 24 hours at $50^{\circ} \mathrm{C}$ is effective to reduce Cronobacter.

\section{Conclusion}

Ampicillin is not effective to inhibit the growth of yeasts, molds and some of lactic bacteria. The suitable enumeration method for mutant enumeration in the presence of indigenous microorganisms is surface plating method on ampicillin supplemented medium combined by UV light application. The cornstarch produced in laboratory has the similar properties with the commercial cornstarch in parameters of moisture content, density, and starch granule structure. Survival analysis during cornstarch production shows that $C$. sakazakii cannot survive in 48 hours soaking at $52^{\circ} \mathrm{C}$ and 24 hours drying step at $50^{\circ} \mathrm{C}$ that is applied during cornstarch production.

\section{Acknowledgements}

This research was supported by funding from a BOPTN Grant (2013) from the Directorate General of Higher Education of Indonesia. 


\section{References}

[1] van Acker, J., de Smet, F., Muyldermans, G., Bouhgatef, A., Naessens, A. and Lauwers, S. (2001) Outbreaks of Necrotizing Enterocolitis Associated with Enterobacter sakazakii in Powdered Milk Formula. Journal of Clinical Microbiology, 39, 293-297. http://dx.doi.org/10.1128/JCM.39.1.293-297.2001

[2] Estuningsih, S., Kress, C., Hassan, A.A., Akineden, Ö., Schneider, E. and Usleber, E. (2006) Enterobacteriaceae in Dehydrated Powdered Infant Formula Manufactured in Indonesia and Malaysia. Journal of Food Protection, 69, 3013-3017.

[3] Meutia, Y.R., Dewanti-Hariyadi, R. and Estuningsih, S. (2008) Characterization of 16S rRNA Gene of Enterobacter sakazakii Isolated from Powdered Infant Formula. In: Indonesian Association of Food Technologists, Eds., Abstracts: Annual Seminar of Indonesian Association of Food Technologists, 14-16 October 2008, Palembang.

[4] Gitapratiwi, D., Dewanti-Hariyadi, R. and Hidayat, S.H. (2012) Genetic Relatedness of Cronobacter spp. (Enterobacter sakazakii) Isolated from Dried Food Products in Indonesia. International Food Research Journal, 19, 1745-1749.

[5] Hamdani, F.W. (2012) Evaluation of Genetic Diversity of Local Isolates of Cronobacter spp. (Enterobacter sakazakii) Isolated from Dried Food. Thesis, Bogor Agricultural University, Bogor.

[6] Food and Agriculture Organization-World Health Organization (FAO-WHO) (2004) Enterobacter sakazakii and Other Microorganisms in Powdered Infant FORMULA. Meeting Report, MRA Series 6, WHO, Geneva.

[7] Dewanti-Hariyadi, R., Gitapratiwi, D., Meutia, Y.R., Hidayat, S.H. and Nurjanah, S. (2010) Isolation of Enterobacter sakazakii (Cronobacter spp.) from Powdered Infant Formula and Other Dried Foods Obtained from Bogor Area. International Seminar on Current Issues and Challenges in Food Safety: Science-Based Approach for Food Safety Management, SEAFAST Center, Bogor.

[8] Fiegen, M. (2010) Untersuchungen zum Vorkommen und zur Tenazität von Cronobacter spp. Dissertation, Universität Hamburg Fachbereich Chemie, Hamburg.

[9] Nurjanah, S., Dewanti-Hariyadi, R., Estuningsih, E. and Suhartono, M.T. (2014) Stability and Growth Characteristics of GFPuv-Labeled Cronobacter sakazakii Isolated from Foods. Food Science and Biotechnology, 23, 1491-1496. http://dx.doi.org/10.1007/s10068-014-0204-3

[10] Rahmawati, Dewanti-Hariyadi, R., Hariyadi, P., Fardiaz, D. and Richana, N. (2013) Isolation and Identification of Microorganisms during Spontaneous Fermentation of Maize. Jurnal Teknologi dan Industri Pangan, 24, 33-39. http://dx.doi.org/10.6066/jtip.2013.24.1.33

[11] Johnson, L.A. and May, J.B. (2013) Wet Milling: The Basis for Corn Bio Refineries. Chapter 12. In: White, P.J. and Johnson, L.A., Eds., Corn: Chemistry and Technology, American Association of Cereal Chemical, Inc., St. Paul, 449494.

[12] Bacteriological Analytical Manual (BAM) (2001) Chapter 3: Aerobic Plate Count. http://www.fda.gov/Food/FoodScienceResearch/LaboratoryMethods/ucm063346.htm

[13] Sharma, S.K., Singh, L. and Singh, S. (2013) Comparative Study between Penicillin and Ampicillin. Scholars Journal of Applied Medical Sciences, 1, 291-294.

[14] Hartanti, A.W. (2007) Screening of Lactic Bacteria that Potential as Probiotic Isolated from Breast Milk. Undergraduate thesis, Bogor Agricultural University, Bogor.

[15] Hummel, A.S., Hertel, C., Holzapfel, W.H. and Franz, C.M.A.P. (2007) Antibiotic Resistances of Starter and Probiotic Strains of Lactic Acid Bacteria. Applied and Environmental Microbiology, 73, 730-739. http://dx.doi.org/10.1128/AEM.02105-06

[16] Haddix, P.L., Paulsen, E.T. and Werner, T.F. (2000) Measurement of Mutation to Antibiotic Resistance: Ampicillin Resistance in Serratia marcescens. Bioscience, 26, 17-21.

[17] Dever, L.A. and Dermody, T.S. (1991) Mechanisms of Bacterial Resistance to Antibiotics. Archives of Internal Medicine, 151, 886-895. http://dx.doi.org/10.1001/archinte.1991.00400050040010

[18] Iversen, C. and Forsythe, S. (2003) Risk Profile of Enterobacter sakazakii, an Emergent Pathogen Associated with Infant Milk Formula. Trends in Food Science \& Technology, 14, 443-454. http://dx.doi.org/10.1016/S0924-2244(03)00155-9

[19] Nazarowec-White, M. and Farber, J.M. (1997) Thermal Resistance of Enterobacter sakazakii in Reconstituted Dried-Infant Formula. Letters in Applied Microbiology, 24, 9-13. http://dx.doi.org/10.1046/j.1472-765X.1997.00328.x

[20] Penna, T.C.V., Ishii, M., Junior, A.P. and Cholewa, O. (2004) Thermal Stability of Recombinant Green Fluorescent Protein (GFPuv) at Various pH Values. Applied Biochemistry and Biotechnology, 114, 469-483. http://dx.doi.org/10.1385/ABAB:114:1-3:469 